\title{
Burnout Syndrome and Self-efficacy Among Nurses
}

\begin{abstract}
Introduction. The aim of this research was to investigate the presence and level of relationship of burnout dimensions with perceived general self-efficacy in relation to the length of service of nurses. Participants were nurse employees of a Cantonal Hospital „Dr.Irfan Ljubijankić” Bihać ( $N=102)$ who work directly with patients.

Materials and Methods. Maslach burnout inventory MBI-HSS. was used to test burnout in the workplace. Generel self-efficacy was measured by a short version of the original general self-efficacy scale by Schwarzer et al.

Conclusion. Research results indicate low level of burnout in the workplace with a tendency towards moderate. More specifically, moderate emotional exhaustion, low depersonalization and high personal accomplishment. Perecived self efficacy is associated with depersonalisation $\left(r_{s}=-0.26, p<0.05\right)$ and personal accopmlishment $\left(r_{s}=0.41, p<0.05\right)$, whilst intention to change profession is affected by perceived self efficacy, emotional exhaustion and personal accomplishment.
\end{abstract}

\section{KEY WORDS:}

burnout syndrome, self-efficacy, intention to change profession

DOI: $10.7251 / S M D 1401025 B$

(Scr Med 2014:45:26-29)

\section{Viktorija Bešević - Comić ${ }^{1}$, Nina Bosankić ${ }^{i}$ Selvira Draganović ${ }^{2}$}

${ }^{1}$ Federal employment institute Sarajevo, 71 ooo Sarajevo

${ }^{2}$ International University of Sarajevo, Hrasnička Cesta 15, 71 ooo Sarajevo 71 ooo Sarajevo

Contact address:

Viktorija Bešević-Ćomić

Telephone:++38761483321

Email:vbesevic@hotmail.com

Submitted: February 22, 2014. Accepted: April 2, 2014.

\section{Introduction}

Burnout syndrome, as defined by Christina Maslach, one of the most famous researchers of this phenomenon in the United States, is „psychological syndrome of emotional exhaustion, depersonalization and reduced personal accomplishment, which usually occurs in people who are somehow working with other people". ${ }^{1}$ Thereby, emotional exhaustion refers to feelings of emotional overload and job exhaustion, while reduced personal accomplishment and depersonalization relates to the negative evaluation of the self and others. Medical professions are, due to specific working environments, psychologically, emotionally and physically enormously demanding. Understanding burnout and its impact on medical personnel is important to all medical institutions in order to appropriately approach, eliminate or mitigate existing or prevent detrimental burnout effects which appear in a form of physical or psychological health problems, work inefficiency, lessened motivation to perform daily tasks, worsening relations with work environment and low life quality in general. ${ }^{2,3}$ Given the amount of the time spend at the workplace and daily communication with nurses, from the perspective of physicians it is useful to know whether burnout syndrome is present among them and how it manifests. An adequate nursing staff and support at all levels within the organization, which is the key to quality patient care, reduces the level of dissatisfaction and occupational burnout and intention to leave medical institution. ${ }^{4}$ Shwarzer et al. ${ }^{5}$ in their survey found that one of the significant individual resources that reduces burnout is perceived self-efficacy, which represents the belief that a person has an ability to organize and perform the actions necessary to accomplish the desired outcomes.

The aim of this study was to investigate the presence, degree and correlation of burnout dimensions, and the relationship with perceived self-efficacy in nurses employed in the Cantonal Hospital " Dr. Irfan Ljubijankić "in Bihac. The intention to resign medical profession in 
relation to the dimensions of burnout and perceived selfefficacy was also investigated.

\section{Patients and Methods}

A questionnaire with clear instructions about research purpose and privacy policy was distributed to participants. It has been noted that all individual data will be protected, and not shared with participants' superiors and colleagues. The survey was voluntary and anonymous. The questionnaire consisted of Maslach burnout inventory MBI-HSS ${ }^{1}$, the general self-efficacy scale ${ }^{5}$ and demographic questionnaire related to personal and social status characteristics such as gender, age, education level and work experience. In addition, respondents were asked to estimate their personal intention to resign the profession and most disturbing factors at their workplace. After establishing satisfactory psychometric properties of the scales and performing descriptive analysis, due to the asymmetry of the distribution of the collected data, Spearman's Rank correlation coefficient and Mann Whitney U - test was used.

Maslach burnout inventory MBI-HSS (Maslach Burnout Inventory for Human Service Survey) consists of 22 items phrased as statements about personal feelings and attitudes, which is self-scored on a seven-point frequency scale, ranging from o (never) to 6 (every day). The three subscales of the MBI-HSS include Emotional Exhaustion (nine items; e.g. "I feel burned out from my work."), Depersonalization (five items; e.g. "I feel I treat some recipients as if they were impersonal objects"), and Personal Accomplishment (eight items; e.g. "I have accomplished many worthwhile things in this job"). High scores on Emotional Exhaustion and Depersonalization and low scores on Personal Accomplishment are indicative of burnout. The subscales represent a related (EE-Emotional Exhaustion and DP- Depersonalization) and independent (PA-Personal Accomplishment) but separate multidimensional concept of the burnout construct.

The scale of general self-efficacy measures general and stable sense of personal efficacy in dealing with a variety of stressful situations. The scale contains 10 statements. Each statement is assessed on a 1-5 Lykert type frequency scale, where 1 means "does not apply to me" and 5 "fully applies to me." Totals score are formed as a linear combination of the estimates. Scales internal consistency, Cronbach alpha for MBI-HSS was 0.78 and for general self-efficacy scale 0.91 .

\section{Results}

Total of 102 respondents participated in this study $(\mathrm{N}=102)$, 87.3\% were females and $12.7 \%$ males. The average age was 35 years (min. 23 and max. 60) and the average length of service (work experience) was 15 years (and min. 2 max. 40).

Results on burnout dimension scale show moderate emotional exhaustion ( $\mathrm{M}=18.71, \mathrm{SD}=10.54)$, low depersonalization $(\mathrm{M}=3.22, \mathrm{SD}=3.83)$ and high personal accomplishment $(\mathrm{M}=42.00, \mathrm{SD}=7.90)$. This indicates a low to moderate level of burnout. Out of total 102 participants, $45.01 \%$ reported moderate emotional exhaustion, $77.61 \%$ low depersonalization and $87.34 \%$ of the high job fulfillment. Research results also indicate that there is statistically significant correlation between emotional exhaustion and depersonalization dimensions with high coefficient of $r_{s}=0.554(p<0.01)$, where higher levels of emotional exhaustion are accompanied by higher levels of depersonalization. When it comes to nurses' perception of own self-efficacy, slightly more than half of the participants perceived high self-efficacy 55.08\% ( $\mathrm{N}=54$ ), while $48.96 \%(\mathrm{~N}=48)$ self assessed low self-efficacy. The existence of relationship between self-efficacy and the two burnout dimensions has been confirmed. Statistically significant negative correlation between low self-efficacy and dimensions of depersonalization $\left(r_{s}=-0.26, p<0.05\right)$ is indicated by research results whereas, participants who perceived higher levels of self-efficacy have lower depersonalization and vice versa. Also, results indicate that self-efficacy is moderately associated with job fulfillment $\left(r_{s}=0.41, p<0.05\right)$, in a way that participants with high self efficacy perceive higher personal accomplishment.

Table 1. Results of the Mann Whitney U-test regarding burnout dimensions, perceived self- efficacy and intention to change profession among nurses

\begin{tabular}{|c|c|c|c|c|c|c|c|c|}
\hline \multirow{3}{*}{ Perceived self efficacy } & \multirow{3}{*}{$\begin{array}{l}\text { Intention to change } \\
\text { profession }\end{array}$} & \multicolumn{7}{|c|}{ Burnout dimensions } \\
\hline & & \multicolumn{2}{|c|}{ Emotional Exhaustion } & \multicolumn{2}{|c|}{ Depersonalization } & \multicolumn{3}{|c|}{$\begin{array}{l}\text { Personal } \\
\text { accomplishment }\end{array}$} \\
\hline & & $\mathrm{N}$ & Midle rank & $p$ & Midle rank & $\mathrm{p}$ & Midle rank & $\mathrm{p}$ \\
\hline \multirow{2}{*}{ Low } & No & 34 & 23.54 & \multirow{2}{*}{ 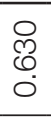 } & 23.50 & \multirow{2}{*}{$\begin{array}{l}\hat{0} \\
0 \\
0 \\
0\end{array}$} & 24.34 & \multirow{2}{*}{$\begin{array}{l}\stackrel{*}{\sim} \\
\stackrel{+}{0} \\
0 \\
0\end{array}$} \\
\hline & Yes & 11 & 21.32 & & 21.45 & & 18.86 & \\
\hline \multirow{2}{*}{ High } & No & 34 & 23.62 & \multirow{2}{*}{ 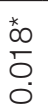 } & 24.29 & \multirow{2}{*}{ 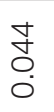 } & 34.25 & \multirow{2}{*}{$\begin{array}{l}\text { * } \\
\stackrel{2}{8} \\
8 \\
0 \\
0\end{array}$} \\
\hline & Yes & 20 & 34.10 & & 32.95 & & 16.02 & \\
\hline
\end{tabular}

Note: Statistically significant differences ${ }^{*} p<0.05 ;{ }^{* *} p<0.01$ 
In regard to intention to leave medical profession (Table 1.) in relation to perceived self-efficacy and burnout dimensions the results indicate that high self efficacious participants with a tendency towards higher emotional exhaustion show a greater intention to change profession than participants with lower emotional exhaustion.

Participants with high level of self-efficacy who find their job fulfilling, to the greatest extent do not intend to leave the job. And participant who are low in self efficacy, and who report higher fulfillment in work, to the greatest extent do not have intention to leave the job.

Participants reported that they are mostly troubled at work by bad interpersonal relationships $(55.92 \%)$ and inadequate allocation of tasks/duties (29.41\%).

\section{Discussion}

Results of this study indicate that surveyed nurses experience moderate emotional exhaustion and job overload. According to Brudnik, ${ }^{6}$ emotional job demands are a major factor in the perception of excess work strain. Research of Aguir-Escriba at al.7 suggests that nurses are more prone to emotional exhaustion if they are exposed to increased psychological demands, with low control over the performance of the work and low support from supervisors and colleagues.

Low depersonalization indicates that there has been no change in relation to patients. Nurses still have interest in patients and are willing to help them. Perceived job fulfillment through personal achievement indicates that surveyed nurses feel competent and successful in their work with patients and possess enthusiasm for the work they do. Perceived self-efficacy as an important factor of belief in their ability to organize and accomplish desired goals is reported by most of the surveyed nurses. However, significant percentage of participant who are not convinced in own, aforementioned capabilities, considering the low, but statistically significant, correlation with depersonalization, should not be ignored. Results of Ebling and Carotta's ${ }^{8}$ study on the relation between self-efficacy and professional dimensions of burnout have been partially confirmed. In our study, relationship between association of depersonalization and personal accomplishment with self-efficacy has been confirmed, in way that nurses with high self-efficacy experience more personal achievements, and lower levels of depersonalization. Self-efficacy may be an effective moderator of burnout, because it prevents the loss of professional satisfaction, reduces exhaustion and depersonalization tendency (Ogresta et al.). ${ }^{9}$ When it comes to intention to leave the profession, personal achievement or sense of fulfillment with a job play important role as well. Nurses who perceived themselves as self efficacious also estimated themselves as more competent and successful in their work with patients. Self-efficacy is an important moderator in occupational burnout syndrome. Results found by Grau et al..$^{10}$ suggests individuals with low self efficacy are more vulnerable to suffer from this syndrome. The intention to leave the profession is significantly affected by the feeling overloaded with work, job fulfillment and self-efficacy ${ }^{11}$ Our findings suggest that nurses who are more fulfilled with the work they do, do not intend to leave the medical profession, regardless of whether they perceive themselves high or low self-efficient.

\section{Conclusion}

Research results indicate that it would be desirable to work on raising the level of self-efficacy, balancing task distribution at work and improving the organizational climate, in order to prevent professional burnout. Therefore organizing various educational workshops to help medical personnel get acquainted with the factors of burnout, as well as workshops with emphasis on increasing feelings of self-efficacy, which we found to be associated with the syndrome of burnout in the workplace, would be of utmost importance to prevent burnout and improve job satisfaction. In addition it would be highly desirable to develop human resources department/human resources teams within medical facilities which would, among other things, facilitate individual and group counseling, work to improve the organizational climate, examine and monitor employee needs and develop training programs in accordance with the needs identified.

\section{References}

1. Maslach C, Jackson SE, Leiter MP. MBI: Maslach Burnout Inventory: Manual. Palo Alto, Consulting Psychologists Press, 1996.

2. Valk M, Oostrom C. Burnout in the medical profession - causes, consequences and solutions. Occup Health Work 2007; 3:1-5.

3. Maslach C, Leither MP. The Truth About Burnout: How Organisations Cause Personal Stress and What to do About it. San Francisco: John Wiley \& Sons Ltd; 1997.

4. Heinen MM, van Achterberg T, Schwendimann R, Zander B, Matthews A, Kózka M, Ensio A, Sjetne IS, Moreno Casbas T, Ball J, Schoonhoven L. Nurses' intention to leave their profession: a cross sectional observational study in 10 European countries. Int J Nurs Stud. 2013 Feb; 5O(2):174-84.

5. Shwarzer R, Hallum S. Perceived teacher self-efficacy as a predictor of job stress and burnout: mediation analyses. Appl Psychol. 2008;57:152-171. doi: 10.1111/j.1464-0597.2008.00359.x.

6. Brudnik M. Perception of self-efficacy and professional burnout in general education teachers. Human movement. 2009; 10 (2):170175. doi: 10.2478/v10038-009-0013-3.

7. Aguir-Escriba V, Martin-Baena D, Perez-Hoyos S. Psychosocial work environment and burnout among emergency medical and nursing staff. Int. Arch Occup Environ Health. 2006; 80: 127-133. doi: 10.1007/s00420-006-0110-y.

8. Ebling M, Carlotto MS. Burnout syndrome and associated factors among health professionals of a public hospital. Trends Psychiatry Psychother [Internet]. 2012 (cited 2014 Feb 27); 34(2): 93- 
100. Avaliable from: http://www.scielo.br/pdf/trends/v34n2/ v34n2ao8.pdf

9. Ogresta J, Rusac S, Zorec L. Relation between Burnout Syndrome and Job Satisfaction Among Mental Health Workers. Croat Med J. 2008; 49 (3): 364-374. doi: 10.3325/cmj.2008.3.364.

10. Grau R, Salanova M, Peiro JM. Moderator effects of self efficacy on occupational stress. Psychology in Spain [Internet] 2001 (cited
2014 Feb 23); 5 (1): 63-74. Available from: http://www.psychologyinspain.com/content/full/2001/7.htm

11. Krausz M, Koslowsky M, Shalom N, Elyakim N. Predictors of intentions to leave the ward, the hospital, and the nursing profession: A longitudinal study. Journal of Organizational Behavior. 1995; 16 (3): 277-288. doi:10.1002/job.4030160308.

\section{Sindrom sagorijevanja na poslu i samoefikasnost kod medicinskih sestara}

\section{APSTRAKT}

Uvod. Cilj ovog istraživanja bio je ispitati stepen prisutnosti i povezanost dimenzija sagorijevanja na poslu sa percipiranom samoefikasnošću i intencijom napuštanja profesije kod medicinskih sestara (N=102) zaposlenih u Kantonalnoj bolnici „Dr. Irfan Ljubijankić" Bihać.

Materijal i metode. Za ispitivanje sindroma sagorijevanja na poslu korišćen je Maslach inventar sagorijevanja na radnom mjestu MBI-HSS. Opšta samoefikasnost je mjerena skraćenom verzijom originalne skale Schwarzera i sar.

Zaključak. Rezultati ukazuju na umjerenu emocionalnu iscrpljenost, nisku depersonalizaciju i visoko lično postignuće. Ispitanici u uzorku imaju nizak stepen sagorijevanja na poslu, sa tendencijom ka umjerenom. Percipirana samoefikasnost je povezana sa depersonalizacijom $\left(r_{s}=-0.26, p<0.05\right)$ i ličnim postignućem $\left(r_{s}=0.41, p<0.05\right)$. Na namjeru napuštanja profesije utiču percipirana samoefikasnost, emocionalna iscrpljenost i lično postignuće.

\section{KLJUČNE RIJEČl:}

Sindrom sagorijevanja na poslu, samoefikasnost, namjera napuštanja profesije 